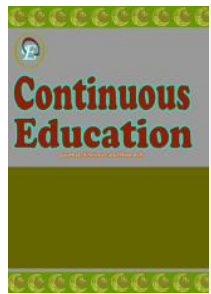

\title{
Kolaborasi Pendidikan Melalui Pertemuan Guru Dan Orangtua
}

\author{
Anita Indria', Elvi Rahmi ${ }^{2}$, M. Yemmardotillah ${ }^{3}$ \\ 1,2,3 STIT Ahlussunnah Bukittinggi, Indonesia
}

Corresponding Author: @ indriaanita87@gmail.com

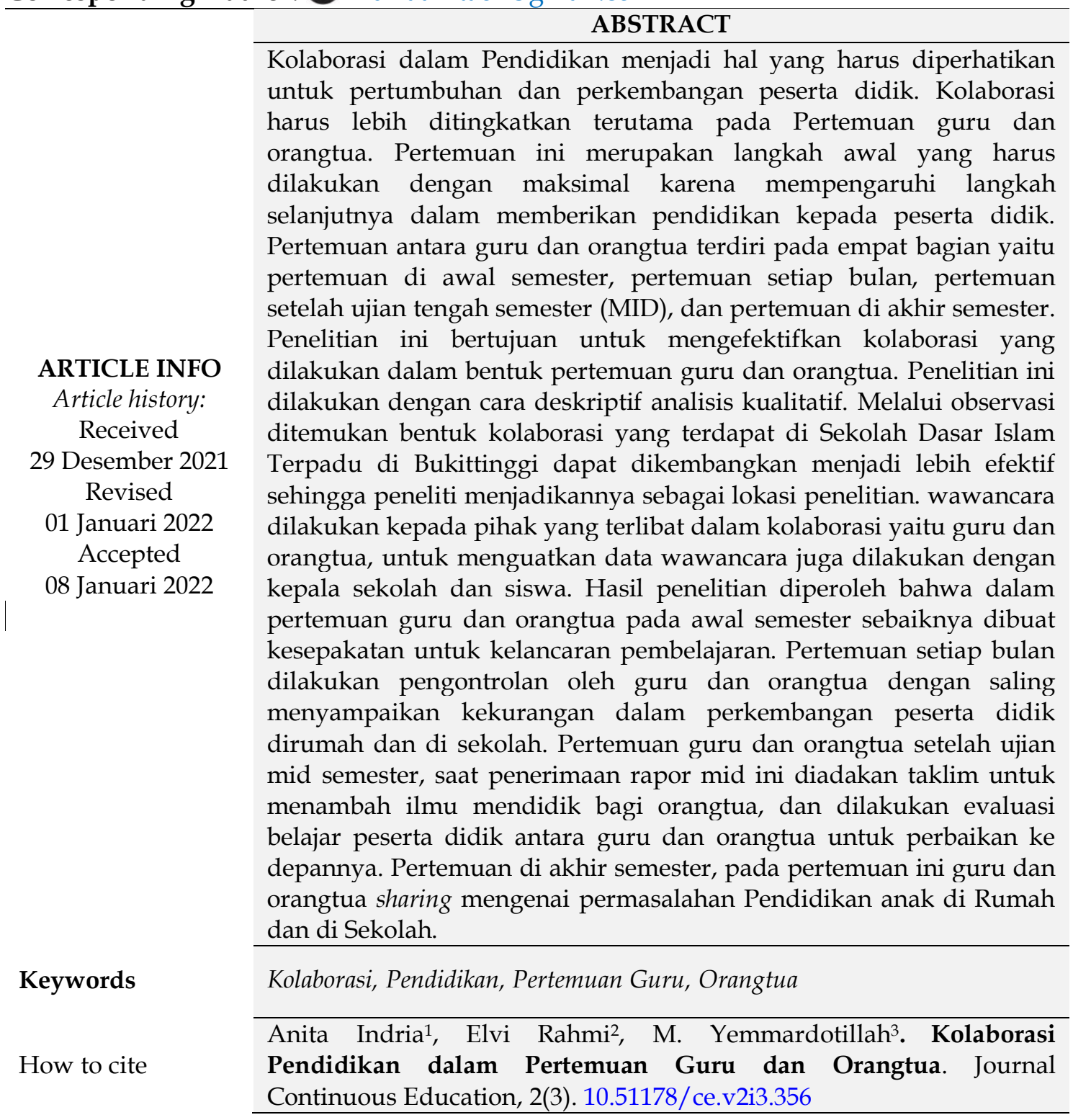

\section{PENDAHULUAN}

Kolaborasi dalam Pendidikan antara guru dan orangtua merupakan hal yang sangat penting (Niharotussadiah, 2021). Kolaborasi mendidik ini dilakukan oleh guru di Sekolah dan orangtua di Rumah sehingga tujuan 
Journal Continuous Education

Volume 2, Issue 3, November 2021

Page 30-47

Pendidikan tercapai (Khadijah, 2020). Kolaborasi ini juga berpengaruh terhadap mutu Pendidikan Sekolah selama guru dan orangtua menjalankan tanggung jawabnya (Nanat Fatah Natsir, 2018) Bentuk kolaborasi yang merupakan keterlibatan orangtua salah satunya dengan mengindahkan setiap pertemuan yang diadakan sekolah. Kolaborasi Pendidikan ini lebih dikenal dengan sebutan Kerjasama di Sekolah yang dilakukan antara guru dan orangtua.

Kerjasama dalam pertemuan dapat berupa rapat yang diadakan pihak sekolah secara umum dan juga berupa rapat yang diundang oleh guru / wali kelas (Yanti dkk, 2013). Pertemuan yang diadakan pihak sekolah merupakan hal yang penting diindahkan dan dihadiri oleh orangtua (Anik Zakariyah, Abdulloh Hamid, 2020), karena dalam pertemuan ini disampaikan kekurangan peserta didik dan perbaikan untuk ke depannya (Rofiatu Nisa dkk, 2020). Hal ini perlu didengar, diperhatikan, dan dijalankan oleh orangtua. Pelaksanaan kerjasama ini tentu diperlukan interaksi antara satu sama lain (Dwi Pratiningsih, 2017).

Interaksi antara keduanya memberikan solusi dari masalah yang ditemukan dalam pertumbuhan dan perkembangan anak didik baik di sekolah maupun di rumah (Eka Faridah Wahyuningtyas, 2018). Orangtua yang memberikan info tentang karakter anak yang sebenarnya di Rumah kepada guru merupakan cara awal untuk memikirkan menghadapi anak didiknya di Sekolah (Henny Sri Rantauwati, 2020). Begitu juga dengan info dari guru merupakan cara selanjutnya yang harus dilakukan orangtua di Rumah dalam menghadapi anaknya (Aulia Suhesty dkk, 2020). Dengan demikian, terjadilah kesesuaian antara guru dan orangtua dalam mendidik anak baik di Sekolah maupun di Rumah (Muammar Qadafi, 2019).

Banyak hal yang perlu dilakukan dalam kolaborasi guru dan orangtua untuk memberikan kontribusi meningkatkan mutu Pendidikan (Nazarudin, 2018). Sebagaimana disampaikan di awal, salah satu kolaborasi yang dilakukan guru dan orangtua adalah melalui pertemuan. Observasi awal yang ditemukan peneliti, pertemuan ini dilakukan di awal sekolah, setiap bulan, mid semester, dan akhir semester. Namun dalam pelaksanaan pertemuan ini tidak berjalan dengan lancar bahkan tidak efektif sehingga terganggunya sistem kerjasama ini. Untuk lebih jelasnya peneliti akan membatasi penelitian ini dalam dua bentuk yaitu implementasi pertemuan guru dan orangtua, pengembangan pertemuan guru dan orangtua. 
Journal Continuous Education

Volume 2, Issue 3, November 2021

Page 30-47

\section{METODE PENELITIAN}

Penelitian ini berupa penelitian deskriptif analisis kualitatif. Hasil penelitiannya diuraikan dalam bentuk narasi (Andi Ibrahim dkk, 2018), sesuai dengan data yang didapatkan di lapangan tanpa adanya perubahan sehingga datanya diolah dan dianalisis menjadi satu kesatuan utuh (Moleong, 2010). Penelitian ini dilakukan di Sekolah Dasar Islam Terpadu yang ada di Bukittinggi. Penelitian ini berawal dari observasi di lokasi dan lingkungan sekitar bahwa banyaknya masalah terjadi pada orangtua yang tidak melakukan bimbingan kepada anaknya di Rumah atau bisa dikatakan orangtua lepas tanggung jawab karena merasa cukup dengan belajar anak di Sekolah saja. Melihat keadaan ini, peneliti tertarik untuk mengetahui dan menguraikan dalam sebuah penelitian tentang bentuk Kolaborasi yang terjadi antara guru dan orangtua di Sekolah. Peneliti memilih Sekolah Dasar Islam Terpadu menjadi sampel dalam penelitian karena tergolong bagus dalam menjalankan Kolaborasinya. Oleh sebab itu, peneliti bisa mendalaminya dan berharap bisa menjadi acuan bagi sekolah lain dalam menjalankan Kolaborasi antara guru dan orangtua.

Selain observasi, peneliti juga mewawancarai guru dan orangtua mulai dari kelas 1 sampai kelas 6 yang diperoleh secara acak. Wawancara dilakukan dengan langsung menemui sumber data satu persatu untuk mendapatkan jawaban dan penguatan dari jawaban yang sebelumnya. Wawancara dilakukan secara mendalam namun tidak terstruktur agar memudahkan peneliti untuk mendapatkan informasi. (Ghony, 2012). Setelah mendapatkan data dari informasi tersebut, peneliti akan membantu mengembangkan bentuk kolaborasi dalam pertemuan guru dan orangtua sehingga dapat efektif dilaksanakan. Peneliti berharap dengan pengembangan yang dilakukan dari data yang didapatkan sesuai dengan keadaan masing-masing antara guru dan orangtua.

\section{HASIL PENELITIAN DAN PEMBAHASAN}

Setelah melakukan penelitian ditemukan beberapa program kolaborasi dalam pertemuan guru dan sekolah. Pertemuan ini dilakukan mulai dari awal semester sampai akhir semester. Pertemuan sekolah dan orangtua Sekolah Dasar Islam Terpadu di Bukittinggi rata-rata dilaksanakan empat kali dalam satu semester, yaitu di awal semester, bulanan, mid semester dan akhir semester/ saat penerimaan. Bentuk Pertemuan guru dan orangtua yang akan dijelaskan dalam uraian dibawah ini. 
Journal Continuous Education

Volume 2, Issue 3, November 2021

Page 30-47

\section{Implementasi Kolaborasi Pendidikan Melalui Pertemuan Guru dan Orangtua}

Berdasarkan penelitian yang telah dilakukan di Sekolah Dasar Islam Terpadu, ditemukan sekolah Dasar ini merupakan sekolah yang cukup bagus pelaksanaan kolaborasinya dibandingkan sekolah yang lain. Akan tetapi kekurangan masih ditemukan disebabkan kurangnya perhatian orangtua, tidak sesuainya jadwal yang ditetapkan guru dengan waktu bekerja orangtua, kurangnya komunikasi antara keduanya dan juga kurang tegasnya guru/pihak sekolah.

Untuk lebih jelasnya, akan diuraikan bentuk implementasi kolaborasi dalam pertemuan guru dan orangtua sebagai berikut:

\section{Awal semester}

Pertemuan di awal semester merupakan proses perkenalan dengan guru dan suasana kelas. Perkenalan ini tidak hanya dengan peserta didik tetapi juga antara guru dan orangtua. Pertemuan ini juga merupakan perkenalan dalam sistim pembelajaran selama satu tahun/satu semester ke depan dengan guru baru/wali kelas. Berdasarkan wawancara dengan kepala sekolah menyatakan bahwa:

"Pertemuan di awal semester ini dilakukan dalam dua hal yaitu pertemuan umum dan pertemuan khusus. Pertemuan umum antara Yayasan dengan orangtua, pertemuan khusus antara wali kelas dan orangtua didalam kelas. Pertemuan ini sangat penting dihadiri orangtua, karena dalam pertemuan ini membahas tentang pembelajaran yang telah terlaksana dan menyampaikan perbaikan pembelajaran ke depannya, disini sangat dibutuhkan Kerjasama dari orangtua."

Pernyataan di atas menjelaskan bahwa pertemuan yang dilakukan sekolah ada dua bentuk pertemuan yaitu pertemuan umum dan pertemuan khusus. Pertemuan umum yaitu sosialisasi yang disampaikan Yayasan dan Kepala Sekolah kepada semua orangtua peserta didik secara keseluruhan. Pertemuan khusus dilakukan di kelas masing-masing disampaikan oleh wali kelas kepada orangtua. Pertemuan ini disampaikan beberapa hal diantaranya tata tertib pembelajaran selama satu tahun ke depan, yang mana tata tertib itu harus dilaksanakan bersama-sama oleh orangtua dan guru. Apabila tidak ditepati dan tidak diindahkan oleh orangtua maka tata tertib yang dilanggar akan tetap dijalankan sekolah sebagaimana mestinya.

Tata tertib yang disepakati di awal ini antaranya; apabila anak tidak membuat Pekerjaan Rumah (PR) akan diberi sanksi, peserta didik harus menggunakan pakaian seragam sesuai dengan peraturan sekolah, orangtua bersedia untuk selalu hadir saat diundang ke sekolah, orangtua 
Journal Continuous Education

Volume 2, Issue 3, November 2021

Page 30-47

memperhatikan peralatan tulis yang dibawa anak ke sekolah, orangtua bersedia/berkenan menerima konsekuensi yang diberikan sekolah apabila ada kesepakatan yang tidak terpenuhi. Berdasarkan kesepakatan ini dalam pelaksanaannya masih banyak ditemukan orangtua yang melanggar. Misalnya saat anaknya disekolah diberi hukuman karena tidak membuat PR, orangtua datang ke sekolah dan menyampaikan ketidakterimaannya, padahal hukuman yang diberikan sesuai dengan perbuatan peserta didik, tidak membuat PR diberi hukuman untuk mengerjakan PR nya diluar kelas sampai selesai atau dipulangkan terlambat dari teman-teman lain agar diselesaikan PR nya terlebih dahulu. Tindakan ini tentu berbeda dari yang disepakati sejak awal, orangtua tidak menjalankan kesepakatan dengan baik sehingga menghambat lancarnya pembelajaran.

\section{Setiap Bulan}

Pertemuan setiap bulan ini diadakan untuk menyampaikan perkembangan peserta didik disekolah. Hal ini perlu dihadiri orangtua agar tau perkembangannya dan kekurangan yang akan ditindaklanjuti bersama. Akan tetapi dalam pertemuan ini ditemukan banyaknya orangtua yang tidak bisa menghadiri dengan alasan waktu dan pekerjaan. Akibatnya kekurangan peserta didik tidak dapat ditindaklanjuti dengan maksimal. Wawancara dengan wali kelas menjelaskan:

"Kami sudah merencanakan dan melaksanakan pertemuan rutin diantaranya sekali sebulan, gunanya adalah agar orangtua mengetahui bagaimana perkembangan anak tiap bulannya, agar orangtua sendiri dapat mengubah cara bimbingan belajar anak di rumah atau menyadari kekurangannya dalam memperhatikan anak".

Sebagian orangtua menyatakan bahwa:

"Saya sering tidak hadir karena saya bekerja wiraswasta, buka toko dari jam

8 pagi sampai jam 6 sore dan itu tidak bisa ditinggal, bagi saya ada atau tidaknya diskusi hari pertemuan sama saja karena waktu kerja saya full day".

Berdasarkan wawancara di atas dapat ditarik kesimpulan bahwa pertemuan setiap bulan tidak selalu dihadiri oleh semua orangtua. Ketidakhadiran orangtua ke sekolah bukan berarti tidak memperhatikan anaknya, akan tetapi karena beberapa hal yang tidak bisa ditinggalkan. Pertemuan ini perlu ditindaklanjut lebih khusus lagi karena berdasarkan wawancara dengan wali kelas/guru, pertemuan bulanan bertujuan untuk memperbaiki kelemahan belajar anak selama satu bulan, tidak tunggu berlamalama untuk memperbaiki kelemahan belajar anak, tiap bulan perlu di bimbing 
Journal Continuous Education

Volume 2, Issue 3, November 2021

Page 30-47

dan diperbaiki sehingga masalah anak tidak semakin parah. Wawancara dengan wali kelas menyatakan:

"pertemuan dengan orangtua juga dilakukan saat penerimaan nilai bulanan

dan mid semester, saat itu juga di ulang menyampaikan target perkelas dan perbaikan Kerjasama untuk kedepannya".

Berdasarkan wawancara di atas dapat dipahami bahwa tujuan dilakukan pertemuan bulanan adalah untuk memperbaiki cara belajar peserta didik dalam waktu satu bulan, sehingga diharapkan bisa diatasi sebelum semakin memburuk. Akan tetapi ditemukan dilapangan bahwa pertemuan sekali sebulan tidak mencapai $50 \%$ dihadiri oleh orangtua peserta didik. Orangtua yang menghadiri pertemuan bulanan itu kebanyakan anaknya yang sedikit memiliki kelemahan belajar, sementara orangtua yang kebanyakan anaknya memiliki kelemahan belajar yang sangat perlu diperbaiki dan disampaikan kepada orangtuanya malah tidak datang. Oleh sebab itu, peneliti mencoba bertanya masalah ini kepada orangtua yang rata-rata menjawab:

"Pertemuan sering diadakan oleh pihak sekolah tentang target dan cara mendidik anak, akan tetapi saya jarang menghadiri pertemuan disebabkan kegiatan/pekerjaan yang tidak bisa ditinggalkan. Jika memang pertemuan itu sangat penting saya berharap kedepannya ada diskusi atau pembagian draft untuk menyepakati pertemuan tersebut, atau pihak sekolah bisa mengadakan pertemuan dihari libur".

Memahami paparan dari orangtua menjelaskan bahwa pertemuan bulanan yang dilakukan pihak sekolah tidak berdasarkan kesepakatan terlebih dahulu. Pertemuan sering dadakan sehingga para orangtua yang kebanyakan sebagai wiraswasta tidak bisa meninggalkan pekerjaan tanpa dikonfirmasi terlebih dahulu. Oleh sebab itu, hal ini perlu ditindaklanjut oleh pihak sekolah agar pertemuan bulan berjalan efektif karena sangat penting dilakukan untuk perbaikan belajar dan sikap anak di rumah dan di sekolah.

\section{Mid semester}

Pertemuan sekolah dan orangtua yang ketiga yaitu saat penerimaan rapor Mid semester. Berdasarkan pernyataan wali kelas:

"Kami juga mengadakan pertemuan saat mid semester untuk melihat dan memberitahu hasil yang diperoleh peserta didik selama pembelajaran sebelumnya. Dan juga agar orangtua mengetahui bahwa bimbingan guru dan orangtua masih ada yang perlu diperbaiki."

Pertemuan yang dilakukan saat penerimaan rapor mid semester merupakan tindak lanjut dari perbaikan kerjasama. Perhatian orangtua terhadap peserta didik dari awal semester sampai mid semester akan mempengaruhi hasil peserta didik untuk ke depannya. Apabila orangtua tidak 
juga mengindahkan pertemuan sampai mid semester akan ditemukan hasil yang lebih buruk lagi terhadap peserta didik karena tidak adanya kesamaan dalam bimbingan antara guru dan orangtua. Bimbingan atau kesepakatan yang dijalankan dalam bentuk Kerjasama dengan orangtua perlu diperbaiki agar tujuan pendidikan tercapai secara optimal. Akan tetapi saat penerimaan rapor mid semester pun tidak semua orangtua yang menghadirinya.

Pertemuan Mid semester ini bertujuan untuk evaluasi belajar, sikap dan pengarahan dari pihak sekolah kepada orangtua terkait cara memperbaiki belajar dan sikap peserta didik. Selain itu, dalam pertemuan ini sebelum penerimaan rapor Mid semester sekolah mengadakan taklim di Mesjid sekolah mengenai cara mendidik anak, cara memberikan perhatian yang tepat kepada anak, dan hal-hal lain yang berkaitan tentang cara mendidik anak. Hal ini sangat penting dihadiri dan didengar oleh orangtua agar tercipta kesamaan dalam Kerjasama mendidik anak di rumah dan di sekolah. Kendala lain pun terjadi saat penerimaan rapor Mid semester ini, tidak semua orangtua yang datang menghadiri acara dalam pertemuan mid semester dari awal waktu, bahkan ada yang datang saat akan menerima rapor saja, tanpa mendengarkan terlebih dahulu taklim yang diadakan oleh pihak sekolah. Kendala ini dikuatkan dengan mewawancara orangtua yang menyatakan bahwa:

"Saya tidak bisa menghadiri acara dari awal waktu karena pekerjaan saya tidak ada yang bisa menggantikan, tetapi kalau ditinggalkan sebentar ada adik atau keluarga lain yang menggantikan."

Pernyataan lain dari orangtua yang berprofesi sebagai guru menyampaikan:

"Saya hanya dibolehkan izin sebentar oleh Kepala Sekolah, tidak bisa berlama-lama karena memang begitu aturan di tempat kerja saya, saran saya agar sekolah tidak mengadakan pertemuan ini disaat jam kerja dan agar disepakati terlebih dahulu."

Berdasarkan wawancara diatas dapat dipahami bahwa pertemuan Mid semester berisi acara taklim yang disampaikan oleh pakar pendidik/psikolog/ceramah agama yang berhubungan dengan pendidikan. Hal ini sangat penting diikuti oleh semua orangtua, agar orangtua yang tidak mengenyam pendidikan tinggi bertambah ilmunya setelah mengikuti taklim. Akan tetapi hal itu menjadi kendala dengan bentroknya hari pertemuan dengan pekerjaan orangtua dan alasan lain sebagaimana dikemukakan oleh orangtua. Oleh sebab itu, hal ini perlu ditindaklanjuti oleh sekolah agar pertemuan Mid semester dihadiri oleh semua orangtua dari awal acara sampai akhir acara. 
Journal Continuous Education

Volume 2, Issue 3, November 2021

Page 30-47

\section{Akhir semester/penerimaan Rapor}

Pertemuan terakhir yang diadakan pihak sekolah adalah pertemuan di akhir semester bertepatan dengan penerimaan rapor. Pertemuan ini merupakan akhir pertemuan wali kelas dengan orangtua dan peserta didik di satu semester, yang tentunya dalam pertemuan ini antara wali kelas dan orangtua sudah merupakan hasil akhir selama satu semester/satu tahun. Sebagaimana wawancara dengan wali kelas IV yaitu:

"Pertemuan akhir semester diisi dengan salam perpisahan dan maaf-maafan dengan peserta didik dan orangtua, jika selama satu tahun ada sikap yang tidak disenangi dan cara yang tidak disukai. Pertemuan ini juga ada sebagian kecil orangtua yang tidak datang, tetapi harus bagaimana lagi, kami sudah berusaha sekuat tenaga dan itu juga bukan tanggung jawab lagi sepenuhnya bagi kami."

Guru kelas lain juga mengungkapkan bahwa:

"Dalam pertemuan akhir semesterpun tidak jauh berbeda dengan pertemuan lainnya, kebanyakan orangtua datang saat akan menerima rapor saja/saat sudah didalam lokal, sementara acara taklim yang diadakan dari pagi jam 09.00 wib masih sebagian yang menghadiri dengan alasan tertentu."

Berdasarkan paparan wali kelas di atas dapat dipahami bahwa orangtua masih sebagian yang mau mengikuti acara saat penerimaan rapor di akhir semester, padahal acara diisi dengan taklim yang sangat bermanfaat bagi orangtua dalam mendidik anak di rumah. Akan tetapi pihak sekolah juga tidak memaksa dan bertindak tegas karena masih ada rasa tidak tega dan sebagainya. Alasan lain ditanya kepada orangtua masih tidak jauh berbeda dengan alasan orangtua lain saat tidak menghadiri pertemuan Mid semester yaitu:

"pertemuan yang diadakan oleh pihak sekolah sebaiknya dilakukan di hari luar sekolah karena setiap hari yang diadakan pihak sekolah untuk pertemuan selalu bertepatan dengan jadwal kerja atau kesibukan lain. pihak sekolah mengadakan pertemuan selalu di hari sabtu untuk orangtua yang kerjanya kantoran, sementara orangtua yang pedagang hari sabtu merupakan hari pasar dan tidak bisa ditinggalkan. Sebaiknya pihak sekolah memberikan angket kepada orangtua untuk menyepakati hari pertemuan, dan memberikan draft kira-kira apa saja yang akan dibicarakan dalam pertemuan itu."

Berdasarkan hasil wawancara dengan orangtua di atas dapat disimpulkan bahwa selama ini yang terjadi pihak sekolah kurang memperhatikan jadwal pertemuan orangtua tanpa melihat rata-rata pekerjaan orangtua peserta didik. Data yang diperoleh tentang pertemuan sekolah dan orangtua adalah kurangnya komunikasi untuk merencanakan, membicarakan hari yang bisa 
diadakan pertemuan antara keduanya. Kesepakatan untuk pertemuan ini perlu di tindaklanjuti oleh pihak sekolah sesuai dengan waktu yang diinginkan orangtua. Namun jika pertemuan ini sudah disepakati secara bersama, tidak ada alasan lain lagi bagi orangtua untuk tidak menghadiri, maka sekolah perlu melakukan tindakan tegas demi lancarnya Kerjasama dan tercapainya tujuan pendidikan dengan optimal.

\section{Pengembangan Pertemuan Guru dan Orangtua}

Uraian dalam implementasi mengenai pertemuan antara guru dan orangtua yang dilakukan mulai dari awal semester, setiap bulan, mid semester, dan akhir semester masih berjalan tidak efektif. Banyak hal yang ditemukan dalam ketidakefektifan pertemuan ini, sehingga peneliti mencoba untuk mengembangkan, memberi saran dan solusi agar efektifnya pertemuan guru dan orangtua ini. Sebelum mengembangkan Kerjasama dalam bentuk pertemuan guru dan orangtua, peneliti akan menyampaikan permasalahannya dalam bentuk bagan dibawah ini:

Gambar 1. Masalah dalam Pertemuan Guru dan Orangtua

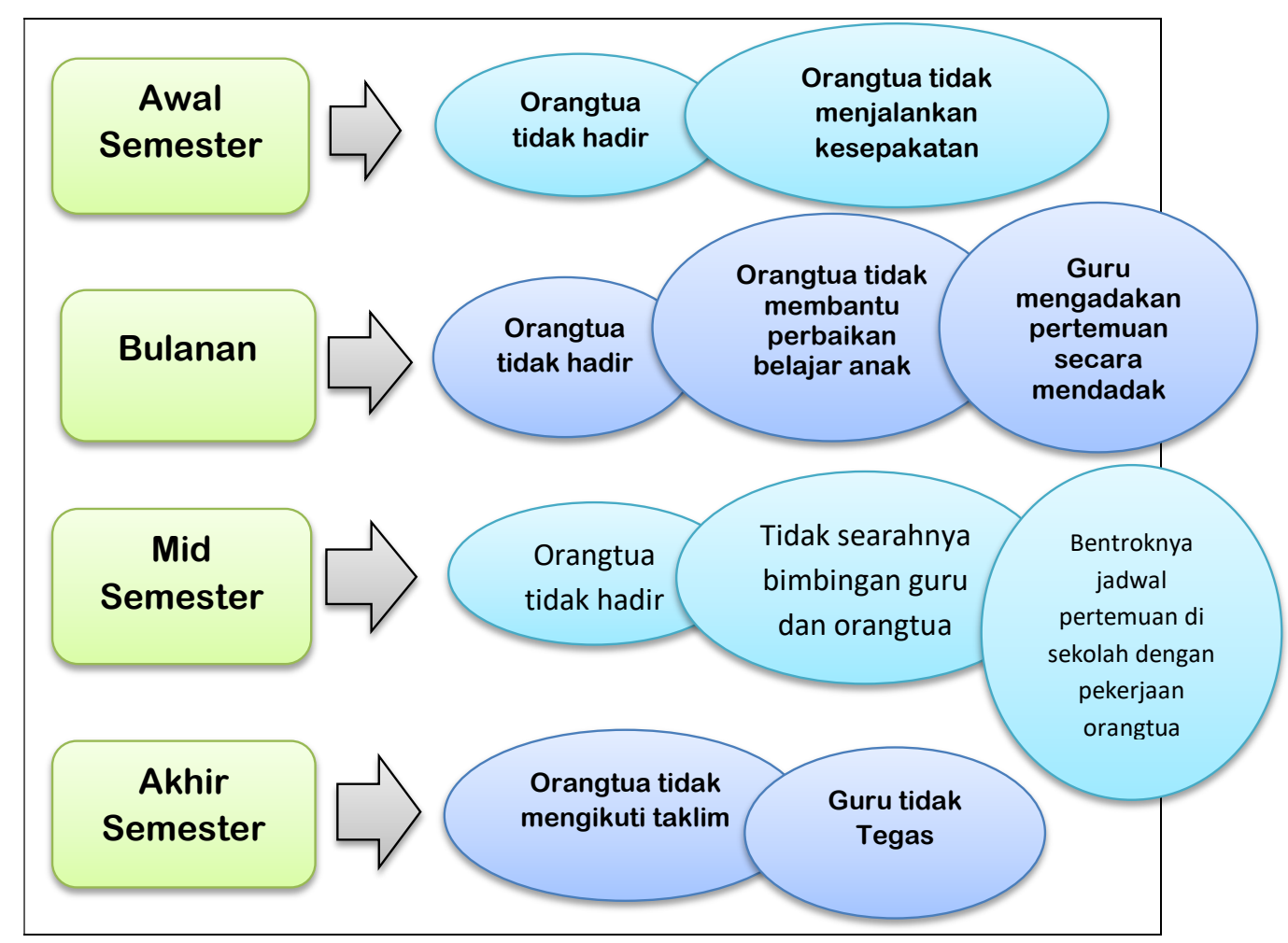

Berdasarkan permasalahan di atas, untuk mengatasinya perlu perbaikan dengan tindak lanjut agar efektifnya pertemuan guru dan orangtua dalam meningkatkan Kerjasama ini. Maka dari itu, peneliti akan mengemukakan satu 
Journal Continuous Education

Volume 2, Issue 3, November 2021

Page 30-47

persatu bentuk pengembangan sesuai dengan poin-poin dalam pertemuan guru dan orangtua.

\section{Awal semester}

Pertemuan antara sekolah dan orangtua yang dilakukan awal semester merupakan hal yang wajib dilaksanakan karena pada pertemuan ini adalah masa perjanjian/kesepakatan antara wali kelas/guru dengan orangtua. Orangtua harus mengetahui apa saja yang menjadi aturan sekolah dan wali kelas, dan yang perlu disepakati demi tercapainya tujuan bersama selama satu semester dan satu tahun nantinya.

Bentuk kegiatan awal semester yang dilakukan adalah:

a. Sosialisasi program sekolah secara umum oleh pihak sekolah.

Sosialisasi ini disebut dengan sosialisasi secara umum karena disampaikan oleh pihak yayasan atau kepala sekolah secara umum, dengan menyampaikan visi misi dan tujuan sekolah. Selain itu, sosialisasi ini juga menyampaikan target yang akan dicapai dalam satu semester atau dalam satu tahun. Kemudian sosialisasi tentang kelemahan yang dialami selama tahun sebelumnya yang diharapkan agar orangtua dan sekolah bersama-sama memperbaiki untuk masa selanjutnya.

Sosialisasi ini harus dilakukan oleh semua pihak sekolah dan orangtua agar sama-sama mendengar dan memahami visi misi, tujuan, target dan kelemahan sekolah sehingga adanya pengetahuan dan keinginan dari semua pihak untuk memperbaiki. Akan tetapi dalam pertemuan sosialisasi ini tidak semua orangtua datang menghadiri. Orangtua pada umumnya mengabaikan sosialisasi yang disampaikan pihak sekolah sehingga berpengaruh pada pelaksanaan kerjasama di masa berikutnya.

Penelitian yang dilakukan ditemukan alasan orangtua tidak mengikuti acara tersebut adalah karena kesibukan dan keperluan lain yang tidak bisa ditinggalkan. Jadwal pertemuan yang dilaksanakan oleh pihak sekolah tidak disepakati terlebih dahulu, tidak menanyakan apakah di waktu yang ditentukan sekolah dapat dihadiri orangtua secara keseluruhan atau tidak.

Berdasarkan kelemahan dari masalah yang muncul peneliti memberikan solusi bahwa pertemuan yang diadakan sebaiknya dilakukan kesepakatan terlebih dahulu. Hal itu dilakukan dengan membagikan draft atau angket kepada orangtua, menyepakati jika pertemuan tidak dihadiri sesuai kesepakatan yang telah dibuat maka 
orangtua bersedia anaknya di skor atau dikeluarkan apabila tidak menghadiri pertemuan lebih dari dua kali.

b. Sosialisasi program sekolah secara khusus oleh wali kelas.

Sosialisasi ini dinamakan sosialisasi secara khusus karena disampaikan di dalam kelas masing-masing oleh wali kelas/guru kepada orangtua. Wali kelas dan orangtua memperkenalkan diri masing-masing dan nama anak mereka yang akan dididik selama satu tahun ke depan. Setelah perkenalan wali kelas menyampaikan target hapalan peserta didik yang harus di kuasai selama satu semester dan satu tahun. Wali kelas juga menyampaikan peraturan yang harus dipatuhi oleh peserta didik dan sanksi bagi yang melanggar peraturan tersebut.

Wali kelas juga menerima saran dan masukan dari orangtua mengenai peraturan yang akan diterapkan. Apabila ditemukan peserta didik yang melanggar, maka sanksi itu akan dilaksanakan sesuai dengan yang sudah disepakati. Peraturan yang disepakati itu antara lain adalah: (1) memberikan tugas 2kali lipat kepada peserta didik apabila tidak mengerjakan PR, (2) menyuruh peserta didik mengerjakan PR diluar kelas apabila tidak mengerjakan PR lebih dari dua kali, dan peraturan lainnya.

Kelemahan yang ditemukan dari hasil sosialisasi secara khusus ini adalah tidak semua orangtua yang bersedia anaknya menjalankan sanksi yang telah disepakati. Sebagian orangtua tidak menerima anaknya dihukum oleh wali kelas bahkan menuntut. Hal ini tidak sesuai dengan kesepakatan yang sudah disetujui kedua pihak. Maka yang terjadi dari tuntutan atau komplain dari orangtua membuat wali kelas membiarkan peserta didik yang tidak mematuhi peraturan. Hal ini tentunya berpengaruh pada keefektifan proses belajar.

Mengatasi ketidakterimaan orangtua dalam menerima anaknya yang menjalankan sanksi/hukuman atas perbuatan dilakukannya, disini guru diharapkan bersikap tegas. Guru harus tetap menjalankan kesepakatan dan sanksi tersebut dengan benar dan tegas.

Pertemuan di awal semester ini sesuai uraian diatas akan dikembangkan agar berjalan efektif digambarkan dalam bagan sebagai berikut: 
Journal Continuous Education

Volume 2, Issue 3, November 2021

Page 30-47

Gambar 2. Bagan Pertemuan Awal Semester:
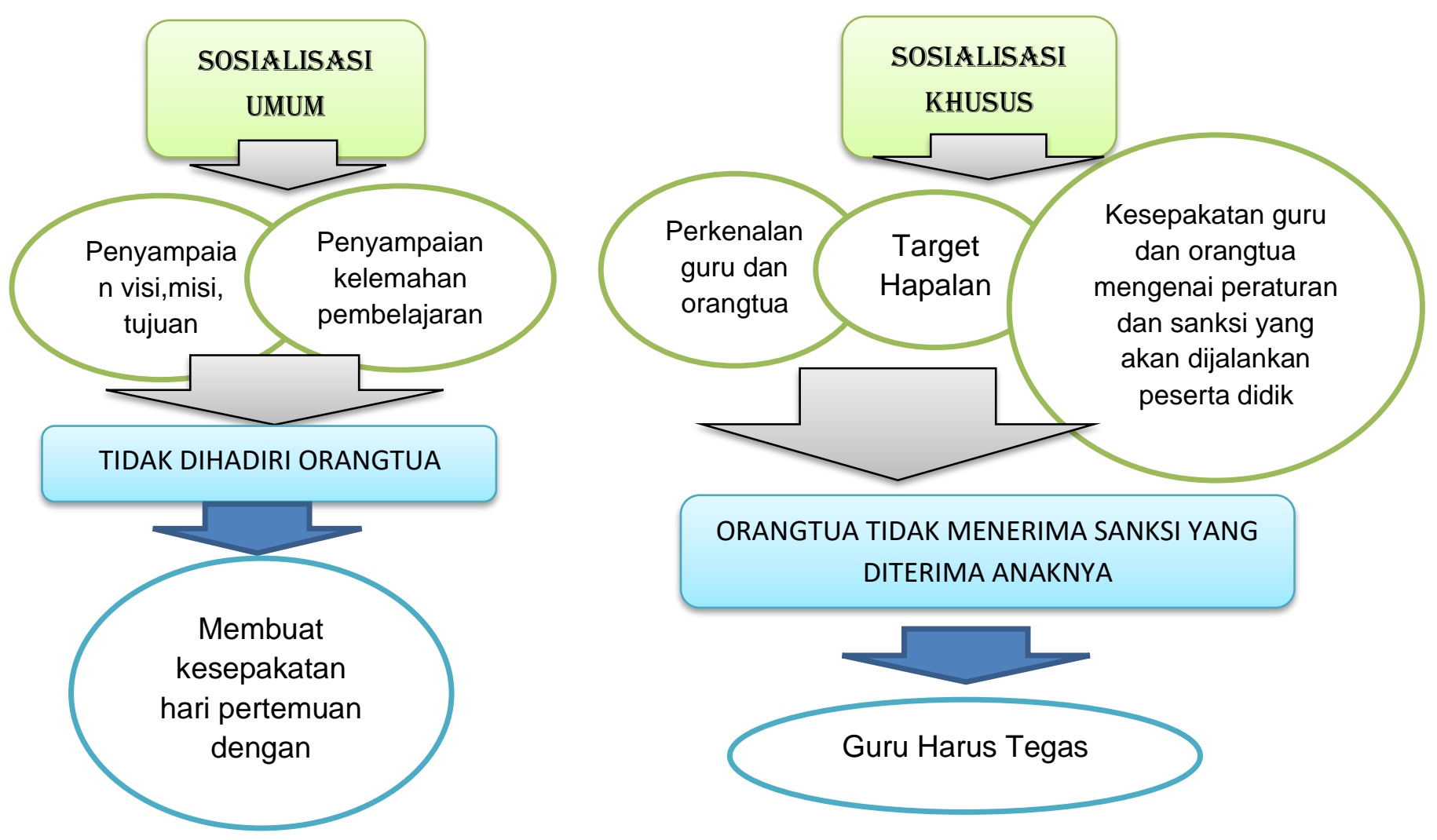

2. Setiap Bulan/ Bulanan

Pertemuan bulanan dilakukan untuk: (1) Evaluasi belajar peserta didik, (2) Evaluasi sikap peserta didik, (3) Penerimaan rapor/ hasil belajar selama sebulan. Pertemuan bulanan dilakukan untuk mengevaluasi belajar, sikap peserta didik dan penerimaan rapor bulanan selama satu bulan, dengan harapan ada perubahan lebih baik lagi pada diri peserta didik. Permasalahan ditemukan selama satu bulan tidak ada perubahan pada peserta didik dengan cara belajarnya dan sikapnya. Permasalahan belajar yang ditemukan adalah peserta didik tidak mau mencatat, peserta didik tidak mau memperhatikan, peserta didik sering tidak membuat $P R$, peserta didik tidak mendengarkan nasehat guru, dan sebagainya. Permasalahan sikap yang ditemukan adalah peserta didik tidak mematuhi peraturan, nasehat guru, dan cuek dengan apapun yang terjadi di kelas.

Permasalahan seperti ini perlu didiskusikan dengan orangtua, saling memberi info, memberi keterangan tentang kelemahan, kekurangan, atau pribadi peserta didik dan bagaimana menghadapinya. Akan tetapi hasil penelitian ditemukan bahwa berdasarkan penjelasan wali kelas justru orangtua yang anaknya 
bermasalah sering tidak datang dalam pertemuan bulanan. Orangtua memberikan alasan adanya kesibukan lain dan keperluan yang tidak bisa ditinggalkan, bahkan ada orangtua yang tidak menghiraukan sama sekali info wali kelas tentang anaknya di sekolah.

Untuk mengatasi masalah ini perlu ketegasan guru untuk memperingati orangtua yang tidak datang ke sekolah. Peringatan ini untuk mengingatkan orangtua kesepakatan yang sudah disepakati di awal apabila tidak dijalankan akan diberikan sanksi. Sanksi tersebut dapat berupa anaknya diberi skorsing/ diberi waktu libur sementara agar bisa belajar dirumah atau mendapatkan perhatian dari orangtua. Apabila belum juga ada perubahan setelah peringatan dan sanksi yang diberikan, guru bisa menyampaikan kepada kepala sekolah untuk memberikan Drop Out (DO) kepada peserta didik agar tidak menyebar ke orangtua lain dalam melalaikan belajar anaknya.

Ketegasan seperti ini perlu dilakukan karena Sekolah Dasar Islam Terpadu merupakan sekolah yang tergolong bagus di saat ini dan banyak orangtua yang menginginkan anaknya sekolah disini. Selain bagus, sekolah ini juga tergolong mahal sehingga dengan dasar ini dalam mendidik anak harus memperhatikan dengan maksimal. Dengan keinginan itu, tentunya harus berdasarkan keinginan untuk bisa diajak bekerjasama dalam mendidik anak.

Gambar 3. Bagan Pertemuan Setiap Bulan/Bulanan

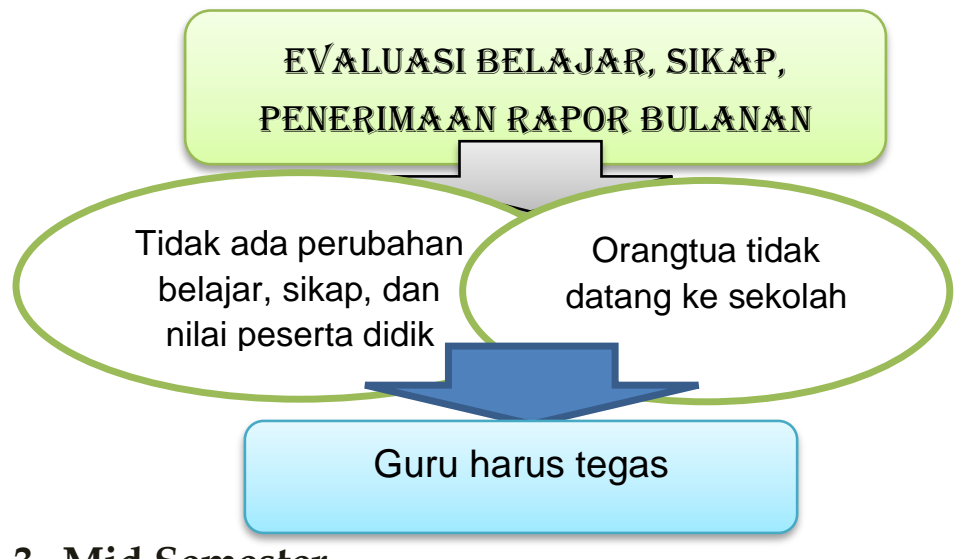

\section{Mid Semester}

Pertemuan mid semester terdiri dari lima kegiatan yaitu evaluasi belajar peserta didik, evaluasi sikap peserta didik, taklim, pengarahan, dan penerimaan rapor. Permasalahan yang ditemukan dalam pertemuan mid semester tidak jauh berbeda dengan pertemuan bulanan. Hanya saja dalam pertemuan ini ada taklim dan pengarahan yang lebih spesifik mengenai pembelajaran sejak awal semester yang dijalankan. Hal ini tentu wajib diketahui dan diikuti oleh orangtua. 
Taklim yang diadakan sekolah mengenai materi cara mendidik anak merupakan suatu hal yang perlu diketahui dan dipahami orangtua. Orangtua yang memiliki pengetahuan mendidik yang minim sangat penting menghadiri taklim, akan tetapi tidak semua orangtua yang menghadiri taklim ini. Kebanyakan orangtua menghadiri pertemuan mid semester saat akan menerima rapor saja yaitu di jamjam terakhir. Sementara ilmu dalam taklim tersebut tidak dipahami oleh semua orangtua, sehingga berpengaruh pada cara mendidik anak dirumah. Hasilnya beberapa peserta didik yang seharusnya ada perubahan ternyata tetap pada cara belajar dan sikap sebelumnya.

Menyikapi hal ini perlu dirembukkan kembali agar guru atau pihak sekolah mengkhususkan waktu untuk orangtua yang tidak bisa hadir. Pengkhususan waktu ini diberikan agar mereka bisa mendengarkan secara langsung taklim yang disampaikan sehingga semua orangtua dapat dipastikan bertambah pengetahuan mendidik mereka. Apabila masih ada orangtua yang beralasan tidak bisa menghadiri taklim yang sudah dikhususkan, guru harus mengambil Tindakan tegas dengan menjalankan sanksi berupa membayar denda. Apabila masih juga tidak diindahkan saknsi tersebut, guru dapat memberlakukan kembali sanksi dengan skorsing dan Drop Out (DO).

Kemudian mengenai evaluasi sikap dan belajar peserta didik yang akan disampaikan kepada orangtua saat penerimaan nilai mid peserta didik, sebaiknya guru membuat peta konsep yang akan disampaikan kepada orangtua. Tujuan dari peta konsep ini adalah untuk mempersingkat waktu sehingga agar terarah dan jelasnya pembahasan yang akan disampaikan kepada orangtua. Hal ini tentu tidak terlalu menghabiskan banyak waktu orangtua di Sekolah.

Lebih jelasnya akan dituangkan dalam bentuk bagan dibawah ini:

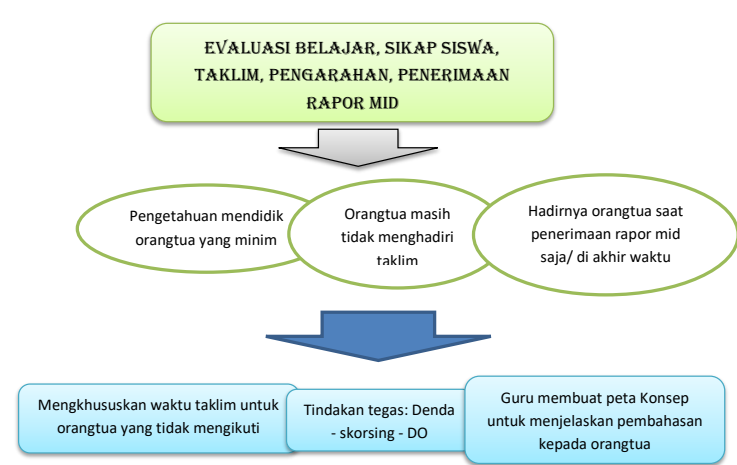

Gambar 4. Bagan Mid Semester 


\section{Akhir semester}

Pertemuan akhir semester adalah pertemuan yang dilakukan saat penerimaan rapor selama satu semester. Pertemuan ini hampir sama dengan pertemuan mid semester. Pertemuan ini juga terdiri dari taklim, evaluasi belajar peserta didik, evaluasi sikap peserta didik, pengarahan dan penerimaan rapor. Taklim yang diadakan sekolah mengenai materi cara mendidik anak yang perlu diketahui dan dipahami orangtua. Orangtua yang memiliki pengetahuan mendidik minim sangat penting menghadiri taklim, akan tetapi tidak semua orangtua yang menghadiri taklim ini.

Orangtua masih juga hanya datang saat akan menerima rapor saja atau di jam-jam terakhir. Sementara ilmu dalam taklim tersebut tidak dipahami oleh semua orangtua, sehingga berpengaruh pada cara mendidik anak dirumah. Pengaruh tersebut berdampak pada semester berikutnya dengan tidak ada perubahan sama sekali pada peserta didik. Hal aneh terjadi saat orangtua sudah menerima rapor anaknya dan melihat bagaimana hasil yang diperoleh selama satu semester. Orangtua di saat ini komplain dan banyak pertanyaan seolah-olah tidak percaya nilai yang diperoleh anaknya rendah, sehingga terkesan menyalahkan guru yang tidak bisa mengajar dan mendidik. Diketahui dari penjelasan guru bahwa biasanya orangtua yang komplain dan tidak menerima nilai anaknya rendah adalah justru orangtua yang tidak pernah hadir tiap pertemuan yang diadakan sekolah. Orangtua pun membela diri dengan alasan anaknya selalu belajar, tetapi saat di tanya guru apakah anaknya di dampingi belajar, mereka diam.

Cara menyikapi kelemahan pada pertemuan akhir semester ini sama dengan pertemuan saat mid semester. Perbedaannya, guru dan orangtua sama-sama sharing atau mencarikan solusi cara menghadapi dan memperbaiki cara belajar peserta didik. Selain itu, guru juga harus mencoba apa yang menjadi kendala orangtua sehingga tidak bisa menghadiri pertemuan yang diadakan sekolah, dan guru membantu mengatasi masalah orangtua tersebut sehingga ditemukan kesepakatan yang lebih baik lagi untuk ke depannya.

Lebih jelasnya akan dituangkan dalam bagan dibawah ini: 


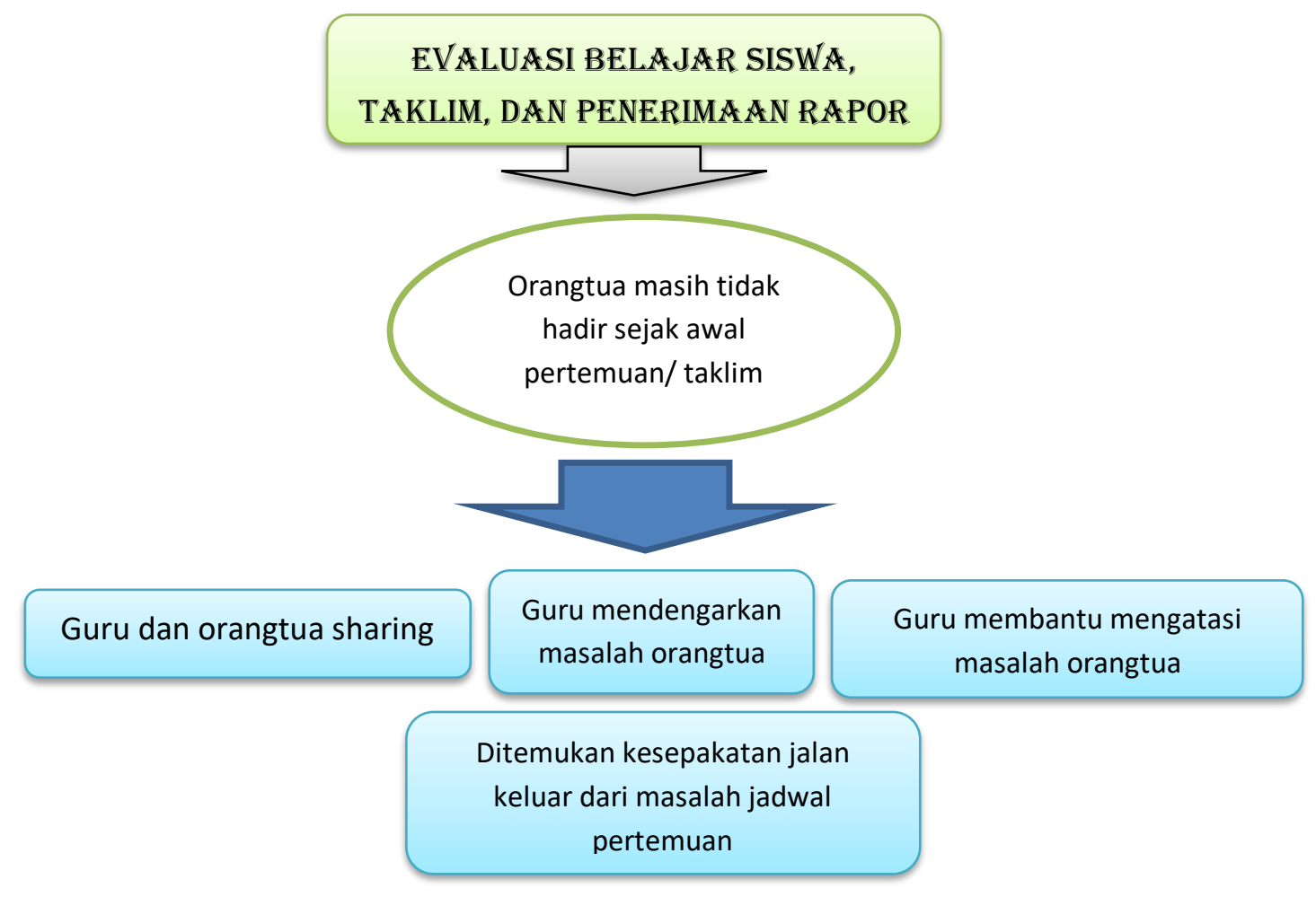

Gambar 5. Bagan Akhir Semester

\section{KESIMPULAN}

Uraian diatas diambil kesimpulan bahwa Pertemuan guru dan orangtua yang merupakan kegiatan dari memperkuat Kerjasama di sekolah patut untuk dilakukan seefektif mungkin. Pertemuan dalam kegiatan Kerjasama ini dilakukan dalam empat kali dalam satu semester yaitu di awal semester, setiap bulan/bulanan, mid semester, dan akhir semester. Pertemuan di awal bulan merupakan kegiatan untuk membuat kesepakatan pembelajaran antara guru dengan anak didik dan orangtua. Pertemuan setiap bulan/bulanan merupakan kegiatan yang dilakukan untuk mengontrol perkembangan anak didik di sekolah dan di rumah. Pertemuan mid semester adalah pertemuan untuk mengevaluasi belajar, sikap siswa sekaligus penambahan ilmu mendidik orangtua melalui taklim yang diadakan sekolah, dan penyerahan nilai mid semester. Terakhir pertemuan yang dilakukan di akhir semester, kegiatan ini hampir sama dengan kegiatan saat pertemuan mid semester, perbedaannya karena ini di akhir semester guru membuka kesempatan untuk orangtua agar bisa sharing mengenai permasalahan pembelajaran anak didik. Selain itu, guru berusaha untuk membantu orangtua mengatasi masalah pembelajaran anak didik sampai ditemukan kesepakatan baru yang disesuaikan dengan keadaan anak didk, orangtua dan guru. Melalui Kerjasama dalam pertemuan guru dan orangtua ini, dan ditemukannya solusi dalam permasalahan yang 
Journal Continuous Education

Volume 2, Issue 3, November 2021

Page 30-47

dikemukakan, penulis berharap dapat dijadikan referensi dan pedoman bagi sekolah dan penulis lain yang membutuhkan.

\section{DAFTAR PUSTAKA}

Ghony ,M. Dzunaidi, Dan Fauzan Almanshur. (2012). Metode Penelitian Kualitatif. Yogyakarta: Ar-Ruzz Media.

Ibrahim, Andy, Dkk. (2018). Metodologi Penelitian. Makassar: Gunadarma Ilmu. Khadijah, Media Gusman. (2020). Pola Kerjasama Guru Dan Orangtua Mengelola Bermain Aud Selama Masa Pandemi Covid-19. Jurnal Kumara Cendekia. Vol. 8 No. 2 Bulan Juni.

Moleong, Lexy J. (2010). Metode Penelitian Kualitatif. Bandung: Remaja Rosdakarya.

Natsir, Nanat Fatah, Ade Aisyah, Dkk. (2018). Mutu Pendidikan: Kerjasama Guru Dan Orangtua. Jurnal Mudarrisuna Vol. 8 No. 2 July-Desember.

Niharotussadiah, Dkk. (2021). Kolaborasi Orang Tua Dan Guru Dalam Mendampingi Anak Usia Dini 5-6 Tahun Menghafal Al-Qur'an Secara Daring. Jce Journal Of Childhood Education. Vol (5), No (1), Edisi Maret.

Nazarudin, Mgs. (2018). Pola Kerja Sama Guru Dan Orang Tua Dalam Meningkatkan Mutu Pendidikan Di Min 2 Kota Palembang. Intizar Vol. 24, No. 2, Desember 2018.

Nisa, Rofiatu, Dkk. (2020). Kerjasama Orang Tua Dan Guru Dalam Meningkatkan Motivasi Belajar Peserta Didik. Ibtida' Media Komunikasi Hasil Penelitian Pendidikan Guru Madrasah Ibtidaiyah. Volume 01, No. 02, November 2020.

Pratiningsih, Dwi. (2017). Efektivitas Kerjasama Guru Dan Orang Tua Dalam Mendukung Pembelajaran Baca Al-Quran Anak Di Sd It Nurul Ishlah Banda Aceh. Jurnal Ilmiah Didaktika Februari. Vol. 17, No. 2, 194-209 2017.

Qadafi, Muammar. (2019). Kolaborasi Guru Dan Orang Tua Dalam Mengembangkan Aspek Moral Agama Anak Usia Dini. Awlady: Jurnal Pendidikan Anak, Vol. 5, No. 1, Maret 2019.

Rantauwati, Henny Sri. (2020). Kolaborasi Orang Tua Dan Guru Melalui Kubungortu Dalam Pembentukan Karakter Siswa SD. Jurnal Ilmiah Wuny Vol. 2 No. 12020.

Suhesty, Aulia, Dkk. (2020). Kolaborasi Peran Guru Dan Orang Tua Dalam Pelaksanaan Pembelajaran Di Era New Normal. Jurnal Plakat Jurnal Pelayanan Kepada Masyarakat. Volume 2 No. 2 Desember 2020.

Wahyuningtyas, Eka Faridah, Afga Sidiq Rifai. (2018). Kerjasama Guru Dengan Orangtua Dan Pengaruhnya Terhadap perilaku Siswa, The 8th University Research Colloquium. Universitas Muhammadiyah Purwokerto. 
Journal Continuous Education

Volume 2, Issue 3, November 2021

Page 30-47

Yanti, Dkk. (2013). Kerjasama Guru Dan Orangtua Guna Meningkatkan Hasil Belajar Sosiologi Siswa Kelas XI Di Sma Pontianak. Jurnal Pendidikan Dan Pembelajaran Khatulistiwa. Vol 2 No. 62013.

Zakariyah, Anik, Abdulloh Hamid. (2020). Kolaborasi Peran Orang Tua Dan Guru Dalam Pembelajaran Pendidikan Agama Islam Berbasis Online Di Rumah. Intizar Vol. 26, No. 1, Juni 2020. 